\title{
Tata Kelola Teknologi Informasi Menggunakan Framework COBIT 2019 (Studi Kasus: UPT TIK Universitas Tanjungpura Pontianak)
}

\author{
Anggi Srimurdianti Sukamto ${ }^{\# 1}$, Haried Novriando ${ }^{\# 2}$, Aldi Reynaldi ${ }^{\# 3}$ \\ \# Program Studi Informatika, Fakultas Teknik, Universitas Tanjungpura \\ Jl. Prof. Dr. H. Hadari Nawawi, Pontianak 78124 \\ langgidianti@informatika.untan.ac.id \\ 2hariedeinformatika.untan.ac.id \\ 3aldireynaldiestudent.untan.ac.id
}

\begin{abstract}
Abstrak-UPT TIK UNTAN merupakan suatu lembaga yang melakukan pengelolaan TI. Tata kelola TI mencakup kepemimpinan, struktur serta proses organisasi yang memastikan bahwa TI dimanfaatkan seoptimal mungkin dan berkonsentrasi pada kinerja dan transformasi TI untuk memenuhi kebutuhan saat ini dan yang akan datang, baik dari sudut internal maupun eksternal. COBIT 2019 adalah kerangka kerja untuk tata kelola dan manajemen informasi dan teknologi perusahaan. Sedangkan COBIT Performance Management merupakan model yang berisi kerangka dasar dalam memberikan panduan untuk menilai dan mengukur tingkat kapabilitas dan tingkat kematangan yang berkaitan dengan proses tata kelola dan manajemen TI. Hasil pengukuran tata kelola TI pada UPT TIK UNTAN dinyatakan bahwa tingkat kapabilitas proses APO08 (Managed Relationships) yang dicapai berada pada tingkat 5. Tingkat kapabilitas proses APO09 (Managed Service Agreements) yang dicapai berada pada tingkat 1. Sedangkan tingkat kapabilitas proses APO11 (Managed Quality) yang dicapai berada pada tingkat 2 . Kesenjangan antara tingkat kapabilitas proses saat ini dan tingkat kapabilitas harapan pada objektif proses APO08 bernilai 0, sedangkan pada objektif proses APO09 dan APO11 bernilai -1. Pada objektif proses APO09 kesenjangannya 2\%, sedangkan pada objektif proses APO11 kesenjangannya 8\%. Berdasarkan hasil analisis, maka diberikan rekomendasi perbaikan yang mengacu pada COBIT 2019 untuk meningkatkan tingkat kapabilitas harapan.
\end{abstract}

Kata kunci- Tata Kelola TI, COBIT 2019, COBIT Performance Management, Tingkat Kapabilitas Proses

\section{Pendahuluan}

Teknologi Informasi (TI), atau dalam bahasa Inggris dikenal dengan istilah Information Technology (IT) adalah istilah umum untuk teknologi apa pun yang membantu manusia dalam membuat, mengubah, menyimpan, mengomunikasikan dan/atau menyebarkan informasi [1].
Dengan adanya pemanfaatan TI, maka perlu diperhatikan tata kelola TI (IT Governance). Tata Kelola TI mencakup kepemimpinan, struktur serta proses organisasi yang memastikan bahwa TI dimanfaatkan seoptimal mungkin. Tata Kelola TI memiliki cakupan yang lebih luas dan berkonsentrasi pada kinerja dan transformasi TI untuk memenuhi kebutuhan saat ini dan yang akan datang, baik dari sudut internal maupun eksternal [2].

Unit Pelaksana Teknis Teknologi Informasi dan Komputer atau disingkat UPT TIK pada Universitas Tanjungpura (UNTAN) Pontianak merupakan suatu lembaga yang melakukan pengelolaan TI. UPT TIK UNTAN memiliki visi pada tahun 2018 - 2022, yakni menjadi pusat pengembangan, pengelolaan, dan pemberi layanan teknologi informasi dan komunikasi yang terkemuka di Kalimantan Barat. Selain itu, UPT TIK UNTAN juga memiliki beberapa misi yaitu meningkatkan pengembangan dan pelayanan teknologi informasi dan komunikasi (TIK) bagi civitas academica UNTAN, meningkatkan kualitas pembelajaran, manajemen, dan budaya TIK yang kondusif dan dinamis di lingkungan UNTAN, serta memberi sumbangsih terhadap kemajuan TIK di Kalimantan Barat [3].

Dalam mewujudkan visi, misi, dan tujuan UPT TIK UNTAN tersebut, tentunya telah diterapkan aturan, standar ataupun prosedur yang digunakan sebagai acuan pada proses tata kelola dan manajemen TI sehingga semua entitas dapat diarahkan dan dikendalikan untuk mencapai tujuan, baik strategi bisnis maupun tujuan terkait TI. Tata kelola TI yang baik berdampak langsung pada peningkatan produktivitas, mutu, dan peningkatan hasil keuangan. Di sisi lain, tata kelola TI yang buruk sering menyebabkan pemborosan program, birokrasi, moral, dan kinerja keuangan yang buruk secara keseluruhan. Tata kelola dan manajemen TI yang efektif didukung oleh kemitraan bisnis 
yang kuat yang bekerja erat dengan kebutuhan bisnis dan sangat penting bagi keberhasilan fungsi TI [4].

Namun kenyatannya, UPT TIK UNTAN masih belum menerapkan suatu kerangka kerja standar yang akan digunakan sebagai tata kelola TI organisasi. Meskipun begitu, UPT TIK UNTAN telah merancang usulan terkait tata kelola TI yang akan diterapkan, mulai dari menentukan aktivtias proses, persyaratan tata kelola TI, prinsip tata kelola TI, model tata kelola TI [5]. Selain itu, terdapat pula usulan perbaikan struktur organisasi maupun definisi peran dan tanggung jawab masing-masing pemangku kepentingannya.

Mengingat struktur organisasi UPT TIK UNTAN saat ini masih belum dijabarkan secara detail, usulan perbaikan struktur organisasi ini dinilai sangat penting terhadap tata kelola dan manajemen TI di UPT TIK UNTAN untuk kedepannya. Karena hal ini sangat berkaitan erat dengan pemberian peran dan tanggung jawab sehingga suatu proses dapat mencapai tujuannya. Dengan adanya usulan perbaikan struktur organisasi, diharapkan hal ini dapat memastikan bahwa kapasitas kepemimpinan memadai dan hubungan antarunit kerja tercipta sinergisitas, baik dalam perencanaan, penganggaran, realisasi sistem TI, operasional sistem TI, dan evaluasi implementasi TI.

Ada beberapa framework atau kerangka kerja yang dapat membantu meningkatkan tata kelola TI organisasi. Misalnya COBIT, ITIL, dan ISO 17799. Dalam ketiga kerangka kerja ini, COBIT memberikan gambaran umum tentang manajemen TI [6]. COBIT 2019 merupakan COBIT versi terbaru dan merupakan penyempurnaan dari $C O B I T$ 5. Seperti diketahui, COBIT 2019 merupakan framework dengan cakupan masalah yang lebih luas serta memberikan fleksibilitas saat digunakan [7]. Selain itu, pada versi COBIT yang diperbarui ini terdapat pembaruan pada struktur dan konten, serta adanya penambahan fitur baru seperti faktor desain yang memungkinkan dalam penyempurnaan sistem tata kelola TI perusahaan [8].

Untuk mengetahui ukuran sejauh mana penerapan suatu proses tata kelola dan manajemen TI di UPT TIK UNTAN, diperlukan suatu penilaian atau audit. Audit tata kelola TI tidak hanya mengidentifikasi kesenjangan dalam manajemen, tetapi juga membantu mengoptimalkan kinerja dan mencapai visi dan misi perusahaan [9]. Dari hasil penilaian tersebut, maka dapat diketahui tingkat kapabilitas atau kemampuan (capability level) pada proses tata kelola dan manajemen TI saat ini [10]. Adapun hasil tersebut kemudian dapat dianalisis dan menghasilkan rekomendasi perbaikan untuk tata kelola dan manajemen TI [11].

Pada kerangka kerja COBIT 2019, terdapat model yang dapat digunakan untuk mengukur seberapa baik suatu proses tata kelola dan manajemen TI yang telah berjalan yaitu model COBIT Performance Management (CPM) [12]. Selain itu, beberapa objektif pada COBIT 2019 dapat digunakan sebagai panduan dalam melakukan pengukuran tingkat kapabilitas suatu proses. Untuk mengukur tingkat kapabilitas proses manajemen mutu, dapat digunakan objektif proses APO11 (Managed Quality) [13]. Kemudian untuk mengukur tingkat kapabilitas proses manajemen hubungan (penyelarasan bisnis dan TI), dapat digunakan objektif proses APO08 (Managed Relationships) [14] Serta untuk mengukur tingkat kapabilitas proses manajemen perjanjian layanan, dapat digunakan objektif proses APO09 (Managed Service Agreements) [15].

Berdasarkan uraian di atas, maka dilakukan penelitian yaitu tata kelola TI menggunakan framework COBIT 2019 dengan area fokus penilaian pada objektif proses APO11, APO08, dan APO09 dengan studi kasus pada UPT TIK UNTAN.

COBIT 2019 dipilih sebagai kerangka kerja untuk melakukan penilaian pada penelitian ini. Pemilihan kerangka kerja ini dikarenakan COBIT sendiri merupakan kerangka kerja umum yang mengadopsi beberapa model umum yang disepakati untuk mengatur proses dan memastikan integritasnya. Selain itu, deskripsi tanggung jawab dan kemampuan semua pemangku kepentingan telah diidentifikasi di dalamnya [16]. Sehingga penggunaan kerangka kerja ini dapat mendukung proses penelitian yang dilakukan.

Penelitian ini bertujuan untuk menilai tingkat kapabilitas proses tata kelola dan manajemen TI saat ini, mengetahui kesenjangannya dan memberikan rekomendasi yang mengacu pada COBIT 2019. Penelitian ini diharapkan dapat dimanfaatkan guna meningkatkan proses tata kelola dan manajemen TI sehingga dapat tercapainya tujuan bisnis maupun tujuan terkait TI di UPT TIK UNTAN, serta meningkatkan pemberian layanan baik untuk internal maupun eksternal.

\section{Metodologi}

Pada penelitian ini, metodologi penelitian yang digunakan mengacu pada kerangka kerja Hevner yaitu kerangka kerja konseptual yang digunakan untuk memahami, melaksanakan, dan mengevaluasi penelitian SI [17]. Terdapat tiga komponen utama dalam terbentuknya penelitian yaitu environmet, knowledge base, dan IS research.

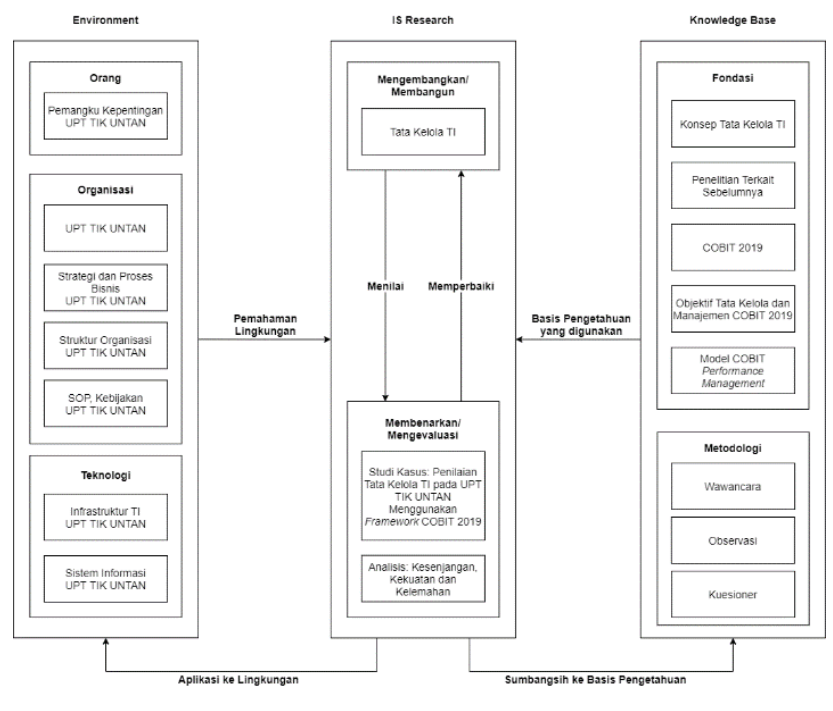

Gambar 1. Kerangka kerja penelitian 
Environment atau lingkungan meliputi beberapa komponen di dalamnya seperti orang, organisasi, dan teknologi. UPT TIK UNTAN merupakan sisi environment. Artinya, dibutuhkan data atau informasi terkait yang dijadikan masukan untuk dilakukannya IS Research. Adapun pemangku kepentingan di UPT TIK UNTAN sebagai individu yang dapat dimintai data atau informasi untuk proses penelitian yaitu Kepala UPT TIK UNTAN beserta para staf.

IS Research merupakan bidang penelitian yang dilakukan. Penelitian yang dilakukan adalah melakukan studi kasus dengan menilai tingkat kapabilitas tata kelola TI pada UPT TIK UNTAN menggunakan kerangka kerja COBIT 2019. Selain itu, dilakukan analisis terhadap hasil penilaian tersebut yaitu analisis kesenjangan serta analisis kekuatan dan kelamahan. Pada proses penelitian, terdapat beberapa tahapan yang dilakukan yaitu studi literatur, inisiasi, perancangan penilaian, pengumpulan data, validasi data, pemeringkatan aktivitas proses, analisis hasil penilaian, dan penarikan kesimpulan.

Knowledge Base merupakan basis pengetahuan yang digunakan dalam melakukan penelitian. Basis pengetahuan yang digunakan adalah penelitian terkait sebelumnya, publikasi COBIT 2019 (termasuk objektif tata kelola dan manajemen, model CPM), serta metode pengumpulan data seperti wawancara, observasi, dan penyebaran kuesioner.

\section{A. Tahapan Penelitian}

Dalam penelitian ini, terdapat beberapa tahapan penelitian yang dilakukan:

1) Studi Literatur: Studi literatur dilakukan dengan mencari referensi yang akan dijadikan basis pengetahuan dalam melakukan penelitian yaitu dokumentasi COBIT, penelitan terkait sebelumnya, buku-buku yang membahas topik penelitian ini, dan jurnal-jurnal ilmiah.

2) Inisiasi: Inisiasi merupakan tahap awal penelitian termasuk di antaranya mengidentifikasi masalah, tujuan dan ruang lingkup penelitian. Selain itu, pada tahap ini dilakukan pengumpulan data dan informasi melalui observasi dan wawancara di UPT TIK UNTAN.

3) Perancangan Penilaian: Perancangan penilaian merupakan kegiatan yang dilakukan sebelum menyebarkan kuesioner penilaian, yaitu dengan menentukan objektif tata kelola dan manajemen TI yang digunakan sebagai area fokus penilaian. COBIT 2019 menyediakan toolkit yang dapat dimanfaatkan guna pemilihan objektif tata kelola dan manajemen TI yang paling sesuai dengan kondisi UPT TIK UNTAN. Setelah memperoleh area fokus penilaian, kegiatan berikutnya adalah menyusun kuesioner berdasarkan sejumlah aktivitas yang telah didefinisikan pada komponen proses pada objektif yang telah dipilih. Setelah itu dilakukan pula penentuan responden yang sesuai di UPT TIK UNTAN dengan RACI chart pada komponen struktur organisasi yang disarankan oleh COBIT 2019.
4) Pengumpulan Data: Setelah dilakukan penyebaran kuesioner melalui google form, tahap selanjutnya adalah mengumpulkan data hasil kuesioner. Data yang dikumpulkan kemudian akan dilakukan validasi dan pemeringkatan aktivitas proses untuk kemudian dilakukan analisis.

5) Validasi Data: Validasi dilakukan terhadap data hasil kuesioner. Tahap ini memastikan kesesuaian antara data hasil kuesioner dengan temuan yang ada di UPT TIK UNTAN. Beberapa validasi data mungkin terjadi ketika data sedang dikumpulkan pada tahap sebelumnya.

6) Pemeringkatan Aktivitas Proses: Pemeringkatan aktivitas proses merupakan kegiatan mengukur tingkat kapabilitas pada tingkat tertentu. Pemeringkatan yang dilakukan berdasarkan pada panduan COBIT 2019. Sehingga, apabila skala pemeringkatan yang didapat pada suatu aktivitas proses tingkat tertentu tidak mencapai kriteria yang ditentukan, maka pengukuran tingkat kapabilitas di tingkat berikutnya tidak dilakukan.

7) Hasil Analisis Penilaian: Setelah didapat hasil penilaian terhadap objektif tata kelola dan manajemen TI saat ini di UPT TIK UNTAN, kemudian dilakukan analisis gap, kekuatan, dan kelemahan. Berdasarkan hasil analisis ini kemudian diberikan rekomendasi perbaikan untuk meningkatkan tingkat kapabilitas harapan yang mengacu pada COBIT 2019.

8) Penarikan Kesimpulan: Pada tahap ini dilakukan penarikan kesimpulan berdasarkan tujuan penelitian yang telah didefinisikan. Selain itu, dikemukakan hasil penilaian pada area fokus tata kelola dan manajemen TI yang dipilih, serta memberi simpulan terkait kesenjangannya, kekuatannya, dan kelemahannya.

\section{B. Tinjauan Pustaka}

1) COBIT 2019: Kerangka kerja untuk tata kelola dan manajemen informasi dan teknologi (I\&T) perusahaan, yang ditujukan untuk seluruh perusahaan [12]

2) Area Fokus: Area fokus mengacu pada area spesifik tata kelola atau masalah yang dapat menangani berbagai tujuan dan komponen tata kelola dan manajemen [12].

3) Faktor Desain: Faktor desain adalah faktor yang mempengaruhi desain sistem tata kelola perusahaan dan menempatkannya untuk keberhasilan penggunaan TI [12]. Faktor desain terdiri atas:

- Strategi Perusahaan

- Tujuan Perusahaan

- Profil Risiko

- Masalah Terkait TI

- Lanskap Ancaman

- Persyaratan Kepatuhan

- Peran TI

- Model Sumber untuk TI

- Strategi Adopsi Teknologi

- Ukuran Perusahaan 
4) Objektif Tata Kelola dan Manajemen TI: Agar informasi dan teknologi dapat berkontribusi pada tujuan perusahaan, sejumlah objektif tata kelola dan manajemen harus dicapai. Objektif tata kelola dan manajemen di COBIT dikelompokkan ke dalam lima domain utama yaitu Evaluate, Direct and Monitor (EDM), Align, Plan and Organize (APO), Build, Acquire and Implement (BAI), Deliver, Service and Support (DSS), dan Monitor, Evaluate and Assess (MEA) [18].

5) Komponen Sistem Tata Kelola: Komponen adalah unsur-unsur yang secara individual dan kolektif berkontribusi pada berfungsinya sistem tata kelola perusahaan melalui TI. Komponen ini bersifat interaktif sehingga menyediakan sistem tata kelola TI yang holistik. Pada COBIT 2019, komponen sistem tata kelola terdiri atas [12]:

- Proses

- Struktur Organisasi

- Prinsip, Kebijakan, dan Prosedur

- Informasi

- Budaya, Etika, dan Perilaku

- Orang, Keterampilan, dan Kompetensi

- Layanan, Infrastruktur, dan Aplikasi

6) Model COBIT Performance Management (CPM): Model ini mencakup konsep dan metode seperti tingkat kapabilitas proses dan tingkat kematangan area fokus. COBIT menggunakan istilah COBIT performance management (CPM) untuk menggambarkan tugas ini. Adapun konsep ini merupakan bagian integral dari kerangka kerja COBIT [12].

7) Tingkat Kapabilitas Proses: Tingkat kapabilitas proses adalah ukuran seberapa baik suatu proses diimplementasikan dan dilakukan. Tiap tingkat kapabilitas proses dapat dicapai apabila tingkat di bawahnya sepenuhnya tercapai (fully achieved) [19]. Berikut karakteristik tingkat kapabilitas proses [12]:

- Tingkat 0: Kurang kapabilitas dasar, pendekatan yang tidak lengkap, mungkin memenuhi atau tidak memenuhi maksud praktik proses.

- Tingkat 1: Proses kurang lebih mencapai tujuannya melalui serangkaian kegiatan yang tidak lengkap, tidak terlalu terorganisir.

- Tingkat 2: Proses mencapai tujuannya melalui penerapan serangkaian kegiatan dasar yang lengkap, dikategorikan beroperasi.

- Tingkat 3: Proses mencapai tujuannya secara terorganisir. Proses biasanya telah didefinisikan dengan baik.

- Tingkat 4: Proses mencapai tujuannya, didefinisikan dengan baik, dan kinerjanya dapat diukur secara kuantitatif.

- Tingkat 5: Proses mencapai tujuannya, didefinisikan dengan baik, kinerjanya diukur, dan perbaikan berkelanjutan dilakukan.
8) Pemeringkatan Aktivitas Proses: Suatu tingkat kapabilitas dapat dicapai dengan derajat yang berbeda-beda, yang dapat diekspresikan dengan serangkaian peringkat yaitu:

- Fully - Tingkat kapabilitas dicapai lebih dari 85 persen.

- Largely - Tingkat kapabilitas dicapai antara 50 persen dan 85 persen.

- Partially - Tingkat kapabilitas dicapai antara 15 persen dan 50 persen.

- Not - Tingkat kapabilitas dicapai kurang dari 15 persen.

9) Tingkat Kematangan Area Fokus: COBIT 2019 mengidentifikasi tingkat kematangan sebagai indikator kinerja di tingkat area fokus. Kematangan terkait dengan bidang prioritas (yaitu, serangkaian objektif tata kelola dan manajemen; dan komponen yang mendasari). Tingkat kematangan tertentu dapat dicapai ketika semua proses di area fokus mencapai tingkat kapabilitas tertentu [12]. Namun, hanya pada komponen proses yang dikemukakan pada COBIT 2019, sehingga untuk mengukur tingkat kematangan belum dimiliki panduan akan hal tersebut. Berikut karakteristik tingkat kematangan area fokus [12]:

- Tingkat 0-Incomplete: Pekerjaan dapat diselesaikan atau tidak dapat diselesaikan untuk mencapai tujuan tata kelola atau manajemen di area fokus.

- Tingkat 1 - Initial: Pekerjaan dapat diselesaikan, tetapi keseluruhan tujuan dan maksud dari area fokus belum tercapai.

- Tingkat 2 - Managed: Perencanaan dan pengukuran kinerja berlangsung meskipun belum secara standar.

- Tingkat 3 - Defined: Standar organisasi menyediakan panduan di seluruh organisasi.

- Tingkat 4 - Quantitative: Organisasi berbasis data dengan peningkatan kinerja kuantitatif.

- Tingkat 5 - Optimizing: Organisasi berfokus pada perbaikan berkelanjutan.

10) RACI Chart: RACI chart adalah bagan yang menjelaskan penugasan tingkat tanggung jawab yang disarankan untuk praktik proses pada peran dan struktur yang berbeda pada kerangka kerja COBIT. RACI chart terdiri atas beberapa peran berbeda yaitu [20]:

- $R$ - Responsible: Peran ini bertanggung jawab mengambil peran utama dalam memenuhi daftar sehingga menciptakan hasil yang diinginkan.

- A-Accountable: Peran ini menetapkan akuntabilitas keseluruhan peran lain sehingga tugas dapat diselesaikan. Peran ini dapat dimintai pertanggungjawaban.

- C-Consulted: Peran ini memberikan masukan atau saran.

- I - Informed: Peran ini memperoleh informasi tentang pencapaian dan/atau kiriman tugas.

11) Analisis Gap: Dalam bisnis dan manajemen, analisis kesenjangan didefinisikan sebagai metrik bisnis yang memungkinkan perusahaan untuk dengan mudah 
membandingkan kinerja aktual dan potensial. Dengan cara ini, dapat diidentifikasi area, bidang, atau kinerja yang perlu diperbaiki atau ditingkatkan. Analisis kesenjangan dapat membantu dalam memahami situasi saat ini dan tindakan apa yang harus diambil di masa depan [21].

12) Analisis Kekuatan dan Kelemahan: Analisis kekuatan dan kelemahan berfokus pada internal. Kekuatan adalah fondasi menjalankan bisnis, dan kelemahan muncul sebagai faktor yang membatasi dan mencegah manajemen mewujudkan potensi yang sebenarnya. Kelemahan mungkin tidak dikenali dan harus diperiksa. Analisis kekuatan dan kelemahan digunakan untuk membuat rekomendasi perbaikan [22].

\section{Perancangan Penilaian}

Dalam merancang penilaian, hal yang paling utama dilakukan adalah menentukan area fokus penilaian yaitu sekumpulan objektif tata kelola dan manajemen TI yang akan dinilai. Setelah menentukan area fokusnya, kemudian dilakukan penyusunan kuesioner berdasarkan komponen proses objektif dan menentukan responden yang sesuai berdasarkan komponen struktur organisasi yang disarankan COBIT 2019.

1) Area Fokus Penilaian: Pemilihan objektif tata kelola dan manajemen TI tertentu yang akan dijadikan area fokus penilaian menggunakan sebuah tools yang telah difasilitasi oleh COBIT yaitu COBIT® 2019 Governance System Design Toolkit [23]. Pada penggunaannya, dilakukan faktor desain dengan pertimbangan hanya pada faktor strategi perusahaan. Faktor strategi perusahaan memiliki value yang telah didefinisikan dan masing-masingnya memiliki tingkat kepentingan yang dapat disesuaikan, yaitu pada rentang 1-5. Pada penelitian ini, pengisian nilai pada tingkat kepentingan didasari oleh hasil analisis yang dilakukan dengan menyesuaikan visi, misi, dan tujuan UPT TIK UNTAN, serta dokumen-dokumen terkait seperti rencana strategis dan blueprint UPT TIK UNTAN. Faktor desain strategi perusahaan dapat dilihal pada tabel I.

TABEL I

FAKTOR DESAIN STRATEGI PERUSAHAAN

\begin{tabular}{|c|l|c|}
\hline No. & \multicolumn{1}{|c|}{ Value } & $\begin{array}{c}\text { Tingkat Kepentingan } \\
(\mathbf{1 - 5})\end{array}$ \\
\hline 1. & Pertembuhan/Akuisisi & 3 \\
\hline 2. & Inovasi/Diferensiasi & 2 \\
\hline 3. & Kepemimpinan Biaya & 3 \\
\hline 4. & Layanan Pengguna/Stabilitas & 5 \\
\hline
\end{tabular}

Setelah menentukan nilai pada tingkat kepentingan masing-masing value, didapat hasil rekomendasi beberapa objektif untuk tata kelola dan manajemen TI seperti terlihat pada gambar 2. Pada gambar tersebut, digambarkan beberapa objektif lebih menonjol daripada objektif yang lainnya. Hal ini mencerminkan rekomendasi objektif yang akan dipilih untuk dinilai yaitu EDM02, APO08, APO09,
APO11, APO13, BAI04, DSS02, DSS03, DSS04, dan DSS05.

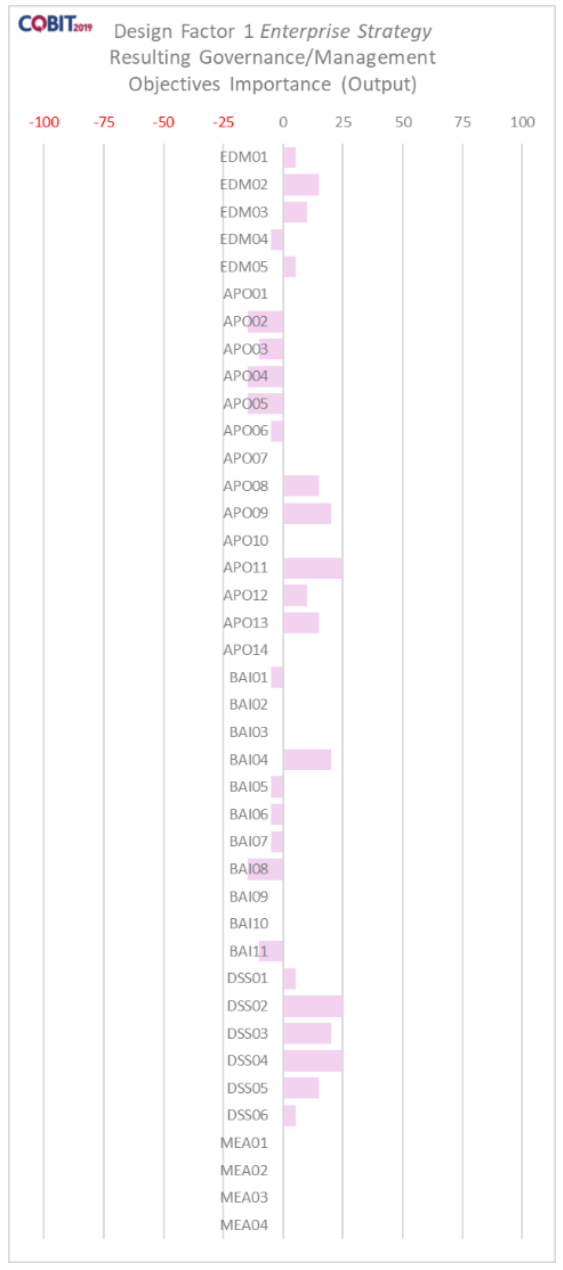

Gambar 2. Hasil faktor desain strategi perusahaan

Namun untuk mempersempit ruang lingkup penilaian, maka dipilihlah beberapa objektif penilaian yaitu pada objektif APO08 yang memfokuskan pada manajemen hubungan antara strategi bisnis dengan strategi TI, APO09 yang memfokuskan pada manajemen perjanjian layanan, dan APO11 yang memfokuskan pada manajemen mutu.

2) Penyusunan Kuesioner: Penyusunan kuesioner dibuat berdasarkan sejumlah aktivitas yang telah didefinisikan pada komponen proses APO08 (Managed Relationships), APO09 (Managed Service Agreements), dan APO11 (Managed Quality) pada kerangka kerja COBIT 2019. Aktivitas-aktivitas ini telah dikelompokkan ke dalam tingkatan tertentu yaitu pada tingkat 2, 3, 4, dan 5. Artinya, dalam pemberian kuesioner akan dilakukan secara bertahap. Hal ini menyesuaikan kriteria yang telah dikemukakan ISACA pada publikasinya terdahulu pada COBIT 5 terkait pencapaian tingkat kapabilitas. Mengikuti aturan tersebut, maka pemberian kuesioner nantinya akan dilakukan secara bertahap. Berikut alur pengisian kuesioner yang dilakukan responden (gambar 3). 


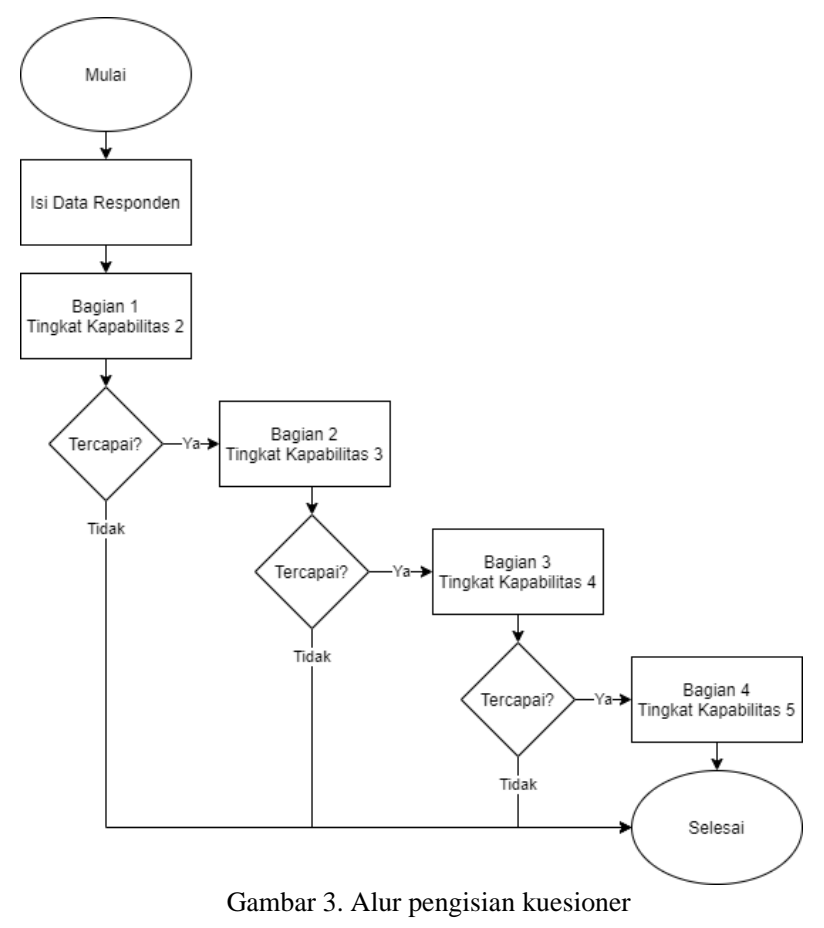

Objektif APO08 memiliki tingkat kapabilitas maksimum pada tingkat kapabilitas 5. Adapun proses APO08 terdiri atas beberapa aktivitas yaitu (gambar 4):

- 7 aktivitas tingkat kapabilitas 2

- 8 aktivitas tingkat kapabilitas 3

- 4 aktivitas tingkat kapabilitas 4

- 2 aktivitas tingkat kapabilitas 5

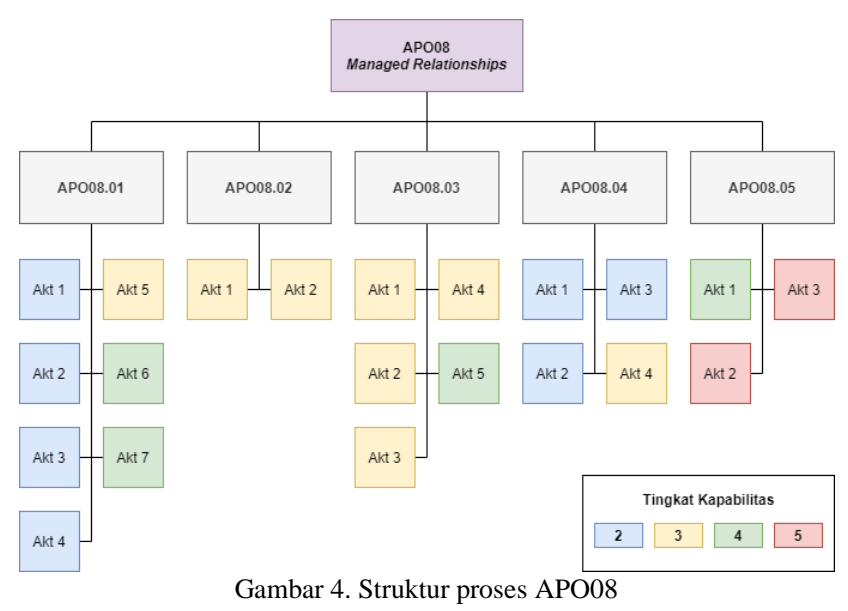

Objektif APO09 memiliki tingkat kapabilitas maksimum pada tingkat kapabilitas 4. Adapun proses APO09 terdiri atas beberapa aktivitas yaitu (gambar 5):

- 6 aktivitas tingkat kapabilitas 2

- 8 aktivitas tingkat kapabilitas 3

- 7 aktivitas tingkat kapabilitas 4

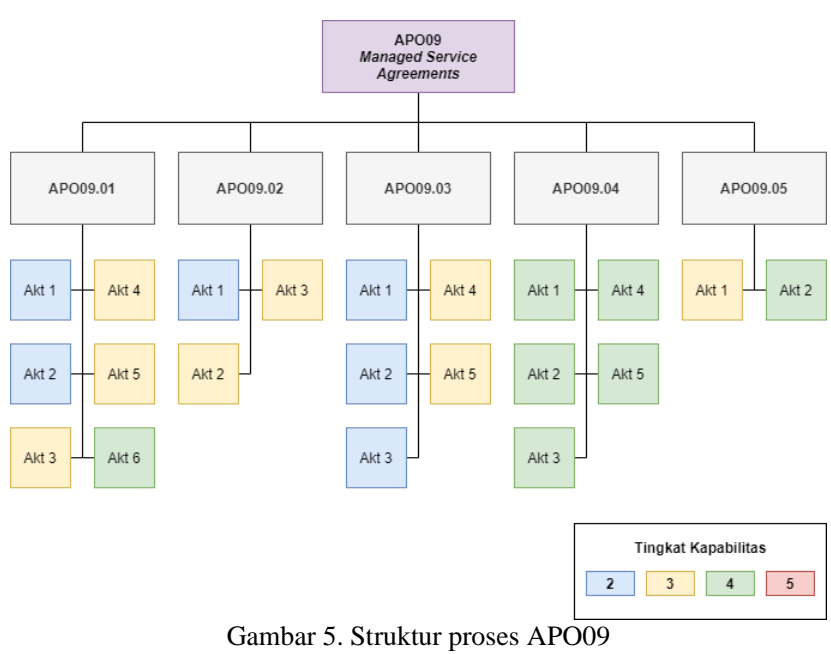

Objektif APO11 memiliki tingkat kapabilitas maksimum pada tingkat kapabilitas 5. Adapun proses APO11 terdiri atas beberapa aktivitas yaitu (gambar 6):

- 2 aktivitas tingkat kapabilitas 2

- 13 aktivitas tingkat kapabilitas 3

- 9 aktivitas tingkat kapabilitas 4

- 2 aktivitas tingkat kapabilitas 5

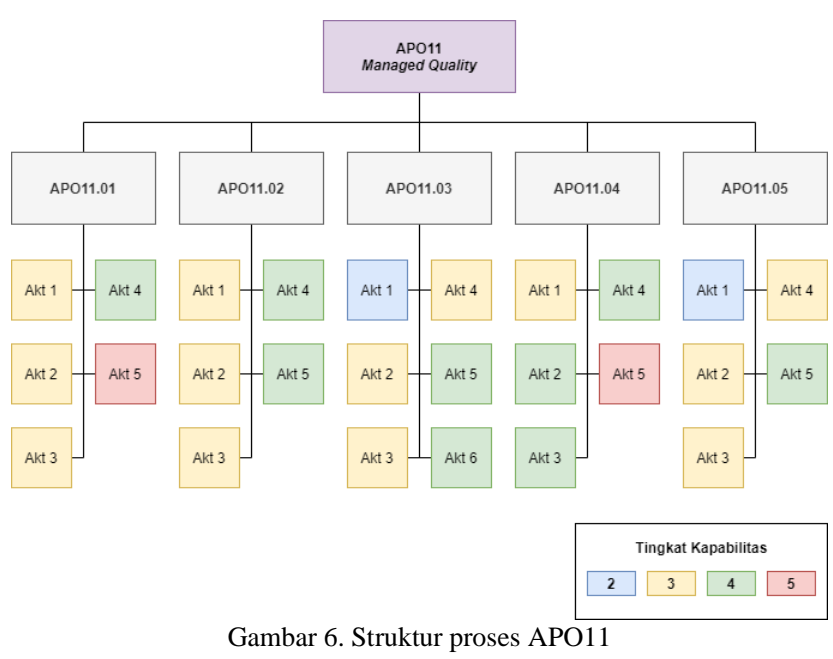

3) Penentuan Responden: Penentuan responden di UPT TIK UNTAN menyesuaikan RACI chart pada komponen struktur organisasi yang disarankan oleh COBIT 2019. Kriteria responden yang sesuai yaitu individu yang memiliki peran accountable atau peran yang dapat dimintai pertanggungjawaban terkait proses tata kelola dan manajemen TI organisasi.

\section{HASIL DAN PEMBAHASAN}

\section{A. Hasil Pengukuran Tingkat Kapabilitas Proses}

Hasil pengukuran tingkat kapabilitas proses APO08, APO09, dan APO11 dapat dilihat pada tabel II. 
TABEL III

Hasil PENGUKuRAN TINGKAT KaPABILITAS PROSES

\begin{tabular}{|c|c|c|c|c|c|c|}
\hline \multicolumn{6}{|c|}{ Hasil Pengukuran Kapabilitas Proses Tingkat 2} \\
\hline No. & $\begin{array}{c}\text { Objektif } \\
\text { Tata Kelola }\end{array}$ & $\begin{array}{c}\text { Jumlah } \\
\text { Aktivitas }\end{array}$ & $\begin{array}{c}\text { Aktivitas } \\
\text { Dijalankan }\end{array}$ & Nilai & Skala \\
\cline { 3 - 5 } 1. & $\begin{array}{l}\text { YPO08- } \\
\text { Managed } \\
\text { Relationships }\end{array}$ & 7 & 6 & 1 & $86 \%$ & F \\
\hline 2. & $\begin{array}{l}\text { APO09- } \\
\text { Managed } \\
\text { Service } \\
\text { Agreements }\end{array}$ & 6 & 5 & 1 & $83 \%$ & L \\
\hline 3. & $\begin{array}{l}\text { APO11- } \\
\text { Managed } \\
\text { Quality }\end{array}$ & 2 & 2 & 0 & $100 \%$ & F \\
\hline
\end{tabular}

Hasil Pengukuran Kapabilitas Proses Tingkat 3

\begin{tabular}{|c|c|c|c|c|c|c|}
\hline \multirow{2}{*}{ No. } & \multirow{2}{*}{$\begin{array}{c}\text { Objektif } \\
\text { Tata Kelola }\end{array}$} & \multirow{2}{*}{$\begin{array}{c}\text { Jumlah } \\
\text { Aktivitas }\end{array}$} & \multicolumn{2}{|c|}{$\begin{array}{c}\text { Aktivitas } \\
\text { Dijalankan }\end{array}$} & \multirow{2}{*}{ Nilai } & \multirow{2}{*}{ Skala } \\
\hline & & & Ya & Tidak & & \\
\hline 1. & $\begin{array}{l}\text { APO08 - } \\
\text { Managed } \\
\text { Relationships }\end{array}$ & 8 & 8 & 0 & $100 \%$ & $\mathrm{~F}$ \\
\hline 2. & $\begin{array}{l}\text { APO11 - } \\
\text { Managed } \\
\text { Quality }\end{array}$ & 13 & 10 & 3 & $77 \%$ & $\mathrm{~L}$ \\
\hline
\end{tabular}

Hasil Pengukuran Kapabilitas Proses Tingkat 4

\begin{tabular}{|c|c|c|c|c|c|c|}
\hline \multirow{2}{*}{ No. } & \multirow{2}{*}{$\begin{array}{c}\text { Objektif } \\
\text { Tata Kelola }\end{array}$} & \multirow{2}{*}{$\begin{array}{c}\text { Jumlah } \\
\text { Aktivitas }\end{array}$} & \multicolumn{2}{|c|}{$\begin{array}{c}\text { Aktivitas } \\
\text { Dijalankan }\end{array}$} & \multirow{2}{*}{ Nilai } & \multirow{2}{*}{ Skala } \\
\hline & & & Ya & Tidak & & \\
\hline 1. & $\begin{array}{l}\text { APO08 - } \\
\text { Managed } \\
\text { Relationships }\end{array}$ & 5 & 5 & 0 & $100 \%$ & $\mathrm{~F}$ \\
\hline
\end{tabular}

Hasil Pengukuran Kapabilitas Proses Tingkat 5

\begin{tabular}{|c|c|c|c|c|c|c|}
\hline \multirow{2}{*}{ No. } & \multirow{2}{*}{$\begin{array}{c}\text { Objektif } \\
\text { Tata Kelola }\end{array}$} & \multirow{2}{*}{$\begin{array}{c}\text { Jumlah } \\
\text { Aktivitas }\end{array}$} & \multicolumn{2}{|c|}{$\begin{array}{c}\text { Aktivitas } \\
\text { Dijalankan }\end{array}$} & \multirow{2}{*}{ Nilai } & \multirow{2}{*}{ Skala } \\
\hline & & & Ya & Tidak & & \\
\hline 1. & $\begin{array}{l}\text { APO08 - } \\
\text { Managed } \\
\text { Relationships }\end{array}$ & 2 & 2 & 0 & $100 \%$ & $\mathrm{~F}$ \\
\hline
\end{tabular}

Berdasarkan tabel II, diketahui pengukuran ketiga objektif dilakukan secara bertahap yaitu mulai dari pengukurang tingkat $2,3,4$, dan 5 . Adapun pengukuran dihentikan apabila nilai yang diperoleh tidak memenuhi skala pemeringkatan $\mathrm{F}(85 \%-100 \%)$.

Pada hasil pengukuran kapabilitas proses tingkat 2 , objektif APO08 mencapai 86\% dan APO11 mencapai 100\% dengan skala pemeringkatan masing-masing $\mathrm{F}$, sehingga kedua objektif ini dapat dilakukan pengukuran pada tingkat 3. Sedangkan pada AP009 hanya mencapai $83 \%$ dengan skala pemeringkatan L, sehingga pada objektif ini tidak dapat dilakukan pengukuran pada tingkat berikutnya. Berdasarkan hasil ini, dinyatakan bahwa objektif APO09 masih berada pada tingkat 1 .

Pada hasil pengukuran kapabilitas proses tingkat 3, objektif APO08 mencapai $100 \%$ dengan skala pemeringkatan $\mathrm{F}$, sehingga objektif ini dapat dilakukan pengukuran pada tingkat 4 . Sedangkan pada AP011 hanya mencapai $77 \%$ dengan skala pemeringkatan L, sehingga pada objektif ini tidak dilakukan pengukuran pada tingkat berikutnya. Berdasarkan hasil ini, dinyatakan bahwa objektif APO11 masih berada pada tingkat 2.

Pada hasil pengukuran kapabilitas proses tingkat 4, objektif APO08 mencapai $100 \%$ dengan skala pemeringkatan $\mathrm{F}$, sehingga objektif ini dapat dilakukan pengukuran pada tingkat 5. Kemudian pada hasil pengukuran kapabilitas proses tingkat 5, objektif APO08 mencapai $100 \%$ dengan skala pemeringkatan $\mathrm{F}$. Berdasarkan hasil ini, dinyatakan bahwa objektif APO08 telah mencapai tingkat 5 .

\section{B. Kesenjangan Tingkat Kapabilitas Proses}

Berdasarkan hasil pengukuran tingkat kapabilitas saat ini yang didapat, maka diketahui nilai kesenjangan antara tingkat kapabilitas saat ini dengan yang diharapkan. Tingkat kapabilitas yang diharapkan yaitu 1 tingkat di atas tingkat kapabilitas saat ini. Berikut gap tingkat kapabilitas pada tabel III.

TABEL III

KESENJANGAN TINGKAT KAPABILITAS PROSES

\begin{tabular}{|l|l|c|c|c|}
\hline No. & Objektif Tata Kelola & $\begin{array}{c}\text { Saat } \\
\text { Ini }\end{array}$ & Harapan & Gap \\
\hline 1. & $\begin{array}{l}\text { APO08 - Managed } \\
\text { Relationships }\end{array}$ & 5 & 5 & 0 \\
\hline 2. & $\begin{array}{l}\text { APO09-Managed Service } \\
\text { Agreements }\end{array}$ & 1 & 2 & -1 \\
\hline 3. & APO11-Managed Quality & 2 & 3 & -1 \\
\hline
\end{tabular}

\section{Analisis Hasil Penilaian dan Kesenjangan}

Dari hasil pengukuran tingkat kapabilitas yang dilakukan terhadap tata kelola dan manajemen TI yang ada di UPT TIK UNTAN, maka analisis hasil penilaian dan kesenjangannya adalah sebagai berikut:

- Pada pengukuran tingkat kapabilitas objektif proses APO08 (Managed Relationships), hasil pengukuran tingkat kapabilitas mencapai pada tingkat maksimum yaitu tingkat 5. Menurut COBIT 2019, pada tingkat ini secara karakteristik proses yang dijalankan telah mencapai tujuannya, terdefinisi dengan baik, kinerjanya diukur untuk meningkatkan kinerja, dan perbaikan berkelanjutan dilakukan. Meskipun telah mencapai tingkat 5, namun pada pembuktiannya, masih banyak terdapat aktivitas yang belum dapat dibuktikan karena kurangnya dokumentasi proses yang dilakukan. 
- Pada tingkat kapabilitas objektif proses APO09 (Managed Service Agreements), hasil pengukuran tingkat kapabilitas mencapai pada tingkat 1 . Meskipun hanya mencapai tingkat 1 , namun sebagian besar aktivitas pada tingkat kapabilitas 2 yang dicapai sudah mencapai $83 \%$. Artinya, hanya perlu perbaikan pada aktivitas yang belum dijalankan sehingga dapat menutupi kurangnya $2 \%$ dari kriteria yang telah ditentukan agar dapat mencapai tingkat kapabilitas 2. Untuk pembuktiannya, sudah terdapat dokumen pendukung atau temuan seperti katalog layanan yang telah didefinisikan pada laman situs UPT TIK UNTAN, meskipun begitu untuk dokumentasi prosesnya terbilang masih belum terdefinisi dengan baik.

- Pada tingkat kapabilitas objektif proses APO11 (Managed Quality), hasil pengukuran tingkat kapabilitas mencapai pada tingkat 2. Meskipun untuk objektif ini hanya mencapai tingkat 2 , namun sebagian besar aktivitas pada tingkat 3 yang dijalankan sudah mencapai $77 \%$. Artinya, hanya perlu perbaikan pada aktivitas yang belum dijalankan sehingga dapat menutupi kurangnya $8 \%$ dari kriteria yang telah ditentukan agar dapat mencapai tingkat kapabilitas 3. Selain itu, pada objektif ini untuk pembuktian dan proses dokumentasinya masih sangat kurang yaitu hanya mengandalkan blueprint UPT TIK UNTAN.

- Kesenjangan yang didapat pada pengukuran ketiga objektif ini adalah hanya manajemen hubungan bisnis dan TI yang mencapai tingkat maksimum, sedangkan untuk manajemen perjanjian layanan dan manajemen mutu masih pada tingkat awal atau dapat dikatakan beroperasi walaupun belum terdefinisi dengan baik. Sehingga dapat dikatakan untuk tingkat kapabilitas manajemen hubungan bisnis dan TI sudah sangat baik, sedangkan untuk tingkat kapabilitas manajemen perjanjian layanan dan manajemen mutu masih kurang baik.

- Kesenjangan antara tingkat kapabilitas objektif proses yang satu dengan yang lainnya dapat dikatakan tidak merata dan beberapa di antaranya cukup besar. Misalnya untuk manajemen mutu dengan manajemen perjanjian layanan, perbedaan tingkat kapabilitas hanya terpaut 1 tingkat. Namun untuk manajemen mutu dengan dengan manajemen hubungan bisnis dan TI perbedaan tingkat kapabilitas terpaut 3 tingkat. Sedangkan untuk manajemen perjanjian layanan dengan dengan manajemen hubungan bisnis dan TI perbedaan tingkat kapabilitas terpaut 4 tingkat.

- Kesenjangan berikutnya yang dirasakan adalah meskipun tingkat kapabilitas tertentu sudah tercapai, namun masih banyak kekurangan di bagian dokumentasi proses sehingga masih sulit untuk dilakukan pembuktiannya.

- Tingkat kesenjangan objektif proses APO08 bernilai 0 karena tingkat kapabilitas yang dicapai telah maksimum. Sedangkan tingkat kesenjangan objektif proses APO09 dan APO11 bernilai -1. Adapun kesenjangan ini hanyalah terpaut beberapa persen saja dari kinerja potensialnya, pada APO09 yaitu 2\% dan APO11 yaitu 8\%. Sehingga apabila beberapa aktivitas dijalankan, maka dapat mencapai tingkat kapabilitas harapan yaitu satu tingkat di atasnya.

- Secara keseluruhan, UPT TIK UNTAN sudah memiliki kesadaran tata kelola TI yang baik. Hal ini diperkuat dengan adanya visi, misi, dan tujuan organisasi yang jelas. Selain itu, adanya dokumen penunjang seperti rencana strategis (renstra) dan cetak biru (blueprint) menunjukkan iktikad baik dalam tata kelola dan manajemen TI sebagai pedoman kerja, proses perencanaan, hingga melakukan evaluasi kedepannya.

\section{Rekomendasi Perbaikan}

Berdasarkan hasil analisis yang telah dilakukan sebelumnya, rekomendasi perbaikan utama yang harus dilakukan UPT TIK UNTAN adalah membuat dokumentasi untuk setiap proses yang ada, sehingga proses dan kesesuaiannya dapat dikelola dengan baik. Selain itu, untuk mencapai tingkat kapabilitas yang diharapkan, yakni 1 tingkat di atas tingkat kapabilitas saat ini, maka diberikan rekomendasi perbaikan yang mengacu pada COBIT 2019.

Meskipun pada objektif proses APO08 telah mencapai tingkat kapabilitas 5, namun masih terdapat beberapa kekurangan atau aktivitas yang belum dijalankan sehingga membutuhkan rekomendasi perbaikan. Berikut rekomendasi perbaikan untuk tiap objektif proses tata kelola manajemen TI tersebut:

1) Rekomendasi perbaikan pada objektif proses APO08 (Managed Relationship):

- Memahami lingkungan bisnis, kendala atau masalah saat ini; perluasan atau kontraksi geografis; dan pendorong industri/peraturan.

- Melakukan pendokumentasian proses tata kelola manajemen TI terkait manajemen hubungan bisnis

2) Rekomendasi perbaikan tingkat kapabilitas 2 pada objektif proses APO09 (Managed Service Agreements):

- Melakukan penilaian terkait layanan dan tingkat layanan I\&T saat ini untuk mengidentifikasi kesenjangan (gap) antara layanan yang ada dan aktivitas yang didukungnya.

- Mengidentifikasi area untuk peningkatan layanan yang ada dan opsi tingkat layanannya.

- Melakukan pendokumentasian proses tata kelola manajemen TI terkait manajemen perjanjian layanan.

3) Rekomendasi perbaikan tingkat kapabilitas 3 pada objektif proses APO11 (Managed Quality):

- Mempertimbangkan manfaat dan biaya sertifikasi mutu. 
- Mengomunikasikan pendekatan manajemen mutu. Misalnya secara teratur melalui program formal pelatihan mutu.

- Memberikan pelatihan kepada karyawan terkait metode atau alat yang dapat digunakan untuk peningkatan berkelanjutan.

- Melakukan pendokumentasian proses tata kelola manajemen TI terkait manajemen mutu.

\section{KESIMPULAN}

Berdasarkan pembahasan sebelumnya, maka dapat disimpulkan bahwa tingkat kapabilitas proses tata kelola dan manajemen TI di UPT TIK UNTAN pada objektif proses APO08 (Managed Relationships) berada pada tingkat maksimum yaitu tingkat 5, pada objektif proses APO09 (Managed Service Agreements) berada pada tingkat 1, dan objektif proses APO11 (Managed Quality) berada pada tingkat 2 .

Kesenjangan antara tingkat kapabilitas proses saat ini dan tingkat kapabilitas harapan pada objektif proses APO08 bernilai 0, sedangkan pada objektif proses APO09 dan APO11 bernilai -1. Pada objektif proses APO09 kesenjangannya $2 \%$, sedangkan pada objektif proses APO11 kesenjangannya $8 \%$.

Rekomendasi perbaikan utama yang harus dilakukan UPT TIK UNTAN adalah membuat dokumentasi untuk setiap proses yang ada, sehingga proses dan kesesuaiannya dapat dikelola dengan baik. Selain itu, untuk mencapai tingkat kapabilitas yang diharapkan, maka diberikan rekomendasi perbaikan yang mengacu pada COBIT 2019.

\section{UCAPAN TERIMA KASIH / ACKNOWLEDGMENT}

Terima kasih kepada para staf dan Kepala UPT TIK UNTAN yang telah berkontribusi dalam penelitian ini, serta para individu-individu yang terlibat dalam terselesaikannya jurnal penelitian ini.

\section{REFERENSI}

[1] B. K. William dan S. C. Sawyer, Using Information Technology: Pengenalan Praktis Dunia Komputer dan Komunikasi. Yogyakarta: ANDI, 2007.

[2] K. Surendro, Implementasi Tata Kelola Teknologi Informasi. Bandung: Informatika, 2009.

[3] UPT TIK UNTAN, Rencana Strategis Teknologi Informasi dan Komunikasi Universitas Tanjungpura 2018 - 2022. Pontianak, 2018.

[4] E. Nachrowi, Yani Nurhadryani, dan Heru Sukoco, "Evaluation of Governance and Management of Information Technology Services Using Cobit 2019 and ITIL 4," J. RESTI (Rekayasa Sist. dan Teknol. Informasi), vol. 4, no. 4, hal. 764-774, Agu 2020, doi: 10.29207/resti.v4i4.2265.

[5] UPT TIK UNTAN, Cetak Biru TIK UNTAN. Pontianak, 2018.

[6] F. Muttaqin, M. Idhom, F. A. Akbar, M. H. P. Swari, dan E. D. Putri, "Measurement of the IT Helpdesk Capability Level Using the COBIT 5 Framework," in Journal of Physics: Conference Series, 2020, vol. 1569, no. 2, doi: 10.1088/1742$6596 / 1569 / 2 / 022039$.
A. W. N. Putra, A. Sunyoto, dan A. Nasiri, "Perencanaan Audit Tata Kelola Teknologi Informasi Laboratorium Kalibrasi Menggunakan COBIT 2019 (Studi Kasus: Laboratorium Kalibrasi BSML Regional II)," J. Fasilkom, vol. 10, no. 3, hal. 241-247, 2020.

[8] D. Steuperaert, "COBIT 2019: A SIGNIFICANT UPDATE,' EDPACS, vol. 59, no. 1, hal. 14-18, Jan 2019, doi: 10.1080/07366981.2019.1578474.

Y. Hendrian, "Analisis Tata Kelola Dan Perencanaan Investasi Teknologi Informasi Dengan Metode Cobit Dan Val It," J. Tek. Komput., vol. 5, no. 1, hal. 105-112, Feb 2019, doi 10.31294/jtk.v5i1.5117.

[10] E. H. Rosmawarni, Ilhamsyah, dan N. Mutiah, "Audi Manajemen Risiko Pengembangan Perangkat Lunak Dengan Menggunakan Framework Cobit 5," Coding J. Komput. dan Apl., vol. 07, no. 1, hal. 54-63, Jan 2019, doi 10.26418/CODING.V7I01.30834.

[11] T. Meiriati, A. S. Sukamto, dan N. Mutiah, "Tata Kelola Manajemen Aset TI Menggunakan Framework COBIT 5 dan ITAM," Coding J. Komput. dan Apl., vol. 8, no. 2, hal. 22-32, Jul 2020, doi: 10.26418/coding.v8i2.41264.

[12] ISACA, COBIT® 2019 Framework: Introduction and Methodology. Schaumburg, USA: ISACA, 2018.

[13] Y. Khairunnisa, "Evaluasi Tata Kelola Teknologi Informasi Menggunakan Framework COBIT 5 (Studi Kasus : Universitas Pembangunan Nasional "Veteran')," Fakultas Sains dan Teknologi UIN Syarif Hidayatullah Jakarta, 2019

[14] G. M. Basil, N. Agitha, dan M. A. Albar, "Analisis Tata Kelola Teknologi Informasi Untuk Meningkatkan Mutu Sumber Daya Manusia Menggunakan Framework COBIT 5 (Studi Kasus: Politeknik Pariwisata Negeri Lombok)," J. Teknol. Informasi, Komputer, dan Apl. (JTIKA ), vol. 1, no. 2, Sep 2019, doi: 10.29303/jtika.v1i2.57.

[15] M. P. Islamiah, "Tata Kelola Teknologi Informasi (IT Governance) Menggunakan Framework COBIT 5 (Studi Kasus: Dewan Kehormatan Penyelenggara Pemilu (DKPP))," UIN Syarif Hidayatullah Jakarta, 2014.

[16] A. Gerl, M. Von Der Heyde, R. Groß, R. Seck, dan L. Watkowski, "Applying COBIT 2019 to IT Governance in Higher Education," Inform. 2020 - Gesellschaft für Inform., hal. 517-539, 2021.

[17] A. R. Hevner, S. T. March, J. Park, dan S. Ram, "Design science in information systems research," MIS Q. Manag. Inf. Syst., vol 28, no. 1, hal. 75-105, 2004, doi: 10.2307/25148625.

[18] ISACA, COBIT® 2019 Framework: Governance and Management Objectives. Schaumburg, USA: ISACA, 2018.

[19] ISACA, COBIT 5: A Business Framework for the Governance and Management of Enterprise IT COBIT 5. Rolling Meadows, USA: ISACA, 2012.

[20] ISACA, COBIT 5 Enabling Processes by ISACA. Rolling Meadows, USA: ISACA, 2012

[21] A. Parasuraman, V. A. Zeithaml, dan L. L. Berry, "A Conceptual Model of Service Quality and Its Implications for Future Research,” J. Mark., 1985, doi: 10.2307/1251430.

[22] S. Nurhayati, "ANALISIS STATEGIS SISTEM TEKNOLOGI INFORMASI DENGAN PENDEKATAN ANALISIS SWOT (Studi Kasus: Divisi IT Rumah Sakit Mata Cicendo Bandung),' Semin. Nas. Inform., vol. 1, no. 5, Jul 2015, Diakses: Jun 24 2021. [Daring]. Tersedia pada: http://jurnal.upnyk.ac.id/index.php/semnasif/article/view/917.

[23] A. M. Fikri, H. S. Priastika, N. Octaraisya, S. Sadriansyah, dan L. H. Trinawati, "Rancangan Tata Kelola Teknologi Informasi Menggunakan Framework COBIT 2019 (Studi Kasus: PT XYZ)," Inf. Manag. Educ. Prof. J. Inf. Manag., vol. 5, no. 1, 2020, doi: $10.51211 /$ imbi.v5i1.1410. 